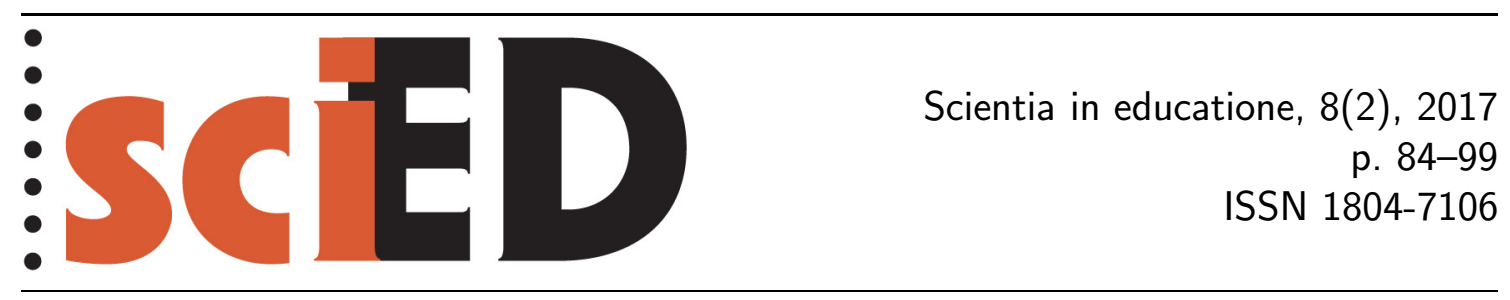

\title{
Profesní vidění studentů učitelství biologie zaměřené na obor a oborově didaktické jevy
}

\author{
Lenka Pavlasová
}

\begin{abstract}
Abstrakt
Profesní vidění představuje jednu z dimenzí učitelské profesionality. Obecná shoda panuje na tom, že by mělo být rozvíjeno v průběhu př́ípravného vzdělávání učitelů. Volba účinných intervencí vyžaduje znalost výchozího stavu dovedností studentů. Předložená studie zjištuje dovednosti všímání si a uvažování založeného na znalostech u budoucích učitelů biologie $(n=26)$ pomocí kvalitativní analýzy písemných reflexí videozáznamu vyučovací hodiny. Použitím kategoriálního systému podle Sherin a van Es (2009) bylo zjištěno, že u studentů převažují výroky zaměřené na učitele, pedagogiku a obecnou didaktiku a že k nim zaujímají převážně hodnotící a popisný přístup. Další analýzy ukázaly, že výroky uváděné ve spojení se žákem jsou ve větší miřre interpretovány než výroky spojené s učitelem, kde převažuje popis a hodnocení. Podrobnější analýza oborových a oborově didaktických komentářủ ukázala jejich tematickou orientaci na dvě širší oblasti: (1) metody, formy, postupy a pojetí výuky a (2) cíl výuky, očekávané výstupy, kompetence, obsah výuky. Mezi opomíjená témata patřily například pomůcky, motivace, aktivizace a pozornost žáků, instrukce učitele. Jen ojediněle studenti komentovali odborné chyby a terminologické nepřesnosti učitele. Tato zjištění poskytují důležité informace garantům kurzů didaktiky biologie.
\end{abstract}

Klíčová slova: profesní vidění, didaktika biologie, všímání si, výběrové zaměření pozornosti, student učitelství biologie.

\section{Professional Vision of Pre-service Biology Teachers Focused on Subject and Subject Didactics Phenomena}

\begin{abstract}
Professional vision represents one dimension of teachers' professionalism. The general consensus is that it should be developed during the standard teacher-training process. In order to choose an effective intervention mechanism, the teacher needs to be familiar with the proficiency of the students at the beginning of the teaching process. The submitted study focuses on pre-service biology teachers $(n=26)$, with the aim of assessing their noticing abilities and knowledge-based reasoning skills. These are detected by a qualitative analysis of written reflections on videos of someone else's teaching. Using the category system
\end{abstract}


devised by Sherin and van Es (2009) it was found that students' reflections contained more statements focused on the teacher and pedagogy, typically expressing a descriptive and evaluative stance. Further analysis showed that statements associated with the pupils were more often interpreted by students than the ones associated with the teacher, where description and evaluation tended to be the predominant stances. Statements associated with subject and subject didactics can be thematically divided into two broad groups: (1) methods, forms, process and concept of teaching and (2) goal of teaching, expected outcomes, competencies, content of teaching. Neglected topics are e.g. teaching aids, motivation, activation and attention of pupils, teacher's instructions and teacher's mistakes. The presented findings provide important information for the guarantors of courses specializing in the didactics of biology.

Key words: professional vision, didactics of biology, noticing ability, selective attention, pre-service biology teacher.

Profesní vidění představuje vedle profesního vědění a profesního jednání jednu z dimenzí učitelské profesionality (Minaříková \& Janík, 2012). Tento pojem byl použit Goodwinem (1994: s. 606) pro označení jednoho ze znaků profesí obecně. Představuje soubor diskurzivních praktik používaných členy profese ke strukturování událostí v oblasti, která je předmětem jejich profesního pozorování. Viděné potom vzniká interakcí pozorovaného právě s těmito diskurzivními praktikami.

Profesní vidění je zkoumáno poměrně často i u učitelské profese, protože učitelovo vnímání situací ve výuce ovlivňuje jeho rozhodování a jednání, čímž může mít důsledky pro kvalitu výuky a výsledky žáků (Minaříková \& Janík, 2012). Profesní vidění se mění v průběhu učitelské přípravy mimo jiné vlivem intervencí během kurzů obecné a oborové didaktiky a pedagogické praxe. Pro vyučující těchto kurzů je přitom důležité mít povědomí, jak rozvinuté profesní vidění mají studenti, kteří do nich vstupují. Podle Svatoše (2013) je malá pozornost věnována výzkumům studentů učitelství na začátku studia a dále nejsou známy žádné výzkumy provedené u studentů učitelství biologie, proto jsme považovali za potřebné tuto mezeru zaplnit.

\section{TEORIE A SOUVISEJÍCÍ VÝZKUM}

Podle Sherin a van Es (2009) má profesní vidění dvě složky: výběrové zaměření pozornosti (selective attention; někdy nazývané též všímání si, noticing) a uvažování založené na znalostech (knowledge-based reasoning). První složka vypovídá o tom, které jevy považuje učitel za důležité ve sledované výuce, a druhá složka o tom, jak o nich uvažuje na základě svých znalostí a zkušeností.

Obecná shoda panuje $\mathrm{v}$ tom, že tyto dovednosti by měly být rozvíjeny v pregraduálním vzdělávání učitelů. Často se $\mathrm{k}$ těmto účelům vedle přímého pozorování výuky využívají videozáznamy výukových situací, kdy studenti řeší s podporou videa různé učební úlohy (viz např. Sonmez \& Hakverdi-Can, 2012; Martin \& Siry, 2012; Simpson, Vondrová \& Žalská, 2017), které mohou být izolované nebo jsou součástí komplexních celků. Ve výuce jsou často využívána elektronická učební prostředí (MOODLE, webové stránky) a speciálně vytvořené kurzy (Sherin \& van Es, 2005; Janík \& Seidel, 2009; Minaříková et al., 2015). Následné zvýšení efektivity výuky učitelů přírodních věd po intervencích s využitím vlastního videa uvádí např̀. 
McConnell et al. (2008). Pozitivní vliv videí jiných učitelů na rozvoj dovedností studentů učitelství prř́rodních věd popisuje Ling Wong et al. (2006).

Obě složky profesního vidění jsou zkoumány zpravidla kvalitativními přístupy u učitelů či studentů učitelství různých předmětů a různého stupně škol. Za všechny jmenujme zejména výzkumy učitelů matematiky (Sherin \& van Es, 2009; Vondrová \& Žalská, 2015), př́rodovědných předmětů (Roth et al., 2011; Talanquer, Tomanek \& Novodvorsky, 2013), anglického jazyka (Uličná, 2017), 1. stupně (Steffensky, 2015; Uličná, Stará \& Novotná, 2017) a preprimárního vzdělávání (Syslová, 2016). Ojediněle jsou prováděny studie učitelů více aprobací (Blomberg, Stürmer \& Seidel, 2011; Pavlasová et al., 2018). Zkoumaným materiálem pak bývají písemné reflexe studentů nebo audiozáznamy jejich diskusí, z nichž je pořízen transkript. Komplexní výpověd' studenta je nejprve tříděna do základních kategorií pomocí kategoriálních systémů (často jsou použivány systémy podle Sherin \& van Es, 2009 a Stockero, 2008) a poté podrobena dalším analýzám.

Sonmez a Hacverdi-Can (2012) zkoumali budoucí učitele př́rodních věd (předmět science) na začátku kurzu využívajícího práci s videi. Zjistili, že si studenti nevšímali detailů výuky a byli schopni pouze částečně rozpoznat hlavní rysy výukové praxe (příprava hodiny, průběh hodiny, kvalita výuky, vedení hodiny). Komentáře většiny účastníků výzkumu se zaměřovaly více na činnost učitele než na žáka. Týkaly se především popisu přítomnosti nebo nepř́tomnosti určitých jevů ve výuce, nebyli schopni posoudit kvalitu výuky a roli žáků ve vzdělávacím procesu. Totéž popisuje např. i Sherin a Han (2004) u učitelů matematiky. V průběhu kurzu pozorovali zlepšení schopnosti všímat si jevů v komplexním prostředí třídy, zlepšilo se výběrové zaměření pozornosti studentů a schopnost všímat si detailů výuky. Dále došlo k pozitivnímu posunu v oblasti hodnocení výuky (schopnost identifikovat silné a slabé stránky výuky).

Seidel et al. (2011) zjistili, že pro učitele př́rodovědných předmětů (předmět science, výuka fyzikálního tématu) je sledování vlastního videa více aktivizující a motivační než sledování videa jiného učitele. Učitelé se zkušenostmi s prací s videem a sledující vlastní video si všímali více složek výuky než učitelé bez těchto zkušeností nebo učitelé sledující video jiného učitele. Výsledky ale nebyly statisticky významné. Mezi učiteli sledujícími video jiného učitele nebyly rozdíly ve všímání si z hlediska prrítomnosti nebo nepřítomnosti jejich předchozích zkušeností s prací s videem. V uvažování o viděném vykazovali učitelé se zkušeností s prací s videem a sledující své vlastní video tendenci k méně četnému uvádění kritických momentů ve výuce.

Blomberg, Stürmer a Seidel (2011) zkoumali profesní vidění u studentů učitelství různých předmětů, mezi jinými i matematiky a předmětu science. Tito studenti vykazovali horší výsledky v profesním vidění než studenti sociálních a humanitních oborů, což ukazuje, že na dovednosti profesního vidění může mít vliv obor, který studenti studují. Ovšem nebylo prokázáno, že dosahují lepších výsledků při sledování výuky oboru, který studují. Z toho autoři vyvozují, že dovednost profesního vidění musí mít obecné aspekty i aspekty vázané na obor.

Vlivu oborového zaměření se věnuje i Steffensky et al. (2015) u studentů učitelství a učitelů prvouky na 1. stupni ZŠ. Profesní vidění považují za specifickou dovednost závislou na oborovém zaměření učitele. Respondenti z obou uvedených skupin, kteří absolvovali předchozí vzdělání orientované na obor (přírodní vědy), vykazovali lepší výsledky v profesním vidění podpory učení žáků (aspektu zaměřeného na obsah) oproti ř́izení tř́dy (pedagogicko-psychologických aspektů výuky nesouvisejících s jejím obsahem) v porovnání s účastníky, kteří tyto zkušenosti s oborem neměli. 
Mezi studenty učitelství středoškolské matematiky a přírodních věd jsou navíc značné intra-individuální rozdíly jak u vstupních dovedností, tak v možnosti jejich dovednosti se rozvíjet, což se ukázalo např. ve výzkumech Stürmer, Seidel a Holzberger (2016) zaměřených na tři úrovně procesu uvažování založeného na znalostech: popis, vysvětlení a predikci.

Z uvedeného vyplývá, že zahraniční výzkumy orientované na učitele přírodovědných předmětů se zabývají především učitelem integrovaného předmětu science zahrnujícího učivo biologie, chemie a fyziky, což odpovídá kurikulárním kontextům daných zemí. Nejsou známy výzkumy učitelů zaměřené na výuku čistě biologických témat. Ani v českém prostředí v podstatě neexistují výzkumy profesního vidění studentů učitelství a učitelů biologie (kromě Vondrová, Robová \& Pavlasová, 2017). Uvedená studie má za cíl tento prostor zaplnit. Jako první v řadě se jeví potřebné zkoumat studenty učitelství na počátku jejich přípravného vzdělávání, aby bylo možné získat povědomí o jejich dovednostech, se kterými budou vstupovat do kurzů didaktiky biologie. Získaná zjištění mohou být významná pro oborové didaktiky a mohou jim pomoci při přípravě nových didaktických kurzů či při modifikacích kurzů stávajících a zaměřit je na konkrétní složky profesního vidění, které jsou méně rozvinuty.

Výzkum si proto klade za cíl odpovědět na tyto výzkumné otázky:

1. Čeho si všímají studenti učitelství biologie při vstupu do učitelského studia na videozáznamu výuky?

2. Kterého tématu se týkají výroky zaměřené na učitele, žáka a tvůrce kurikula a jaký je charakter uvažování o viděném v těchto výrocích?

3. Jaké je tematické zaměření výroků týkajících se oboru a oborové didaktiky?

\section{Metodologie}

\section{1 ÚČASTNÍCI VÝZKUMU A SBĚR DAT}

Účastníky výzkumu bylo 26 studentů navazujícího magisterského studia oboru učitelství všeobecně vzdělávacích předmětů pro 2. stupeň Z ̌S a SS̆ - biologie, kteří byli na začátku studia (tj. na začátku zimního semestru 1. ročníku). S nabídkou na účast ve výzkumu byli osloveni všichni studenti ročníku (41), ve výsledku reflexe odevzdala jen část studentů (63,4\%), konkrétně 20 žen a 6 mužů. Před nástupem do učitelského studia absolvovali oborové bakalářské studium, které obsahovalo teoretické základy pedagogicko-psychologických disciplín, konkrétně kurzy Základy psychologie, Psychologii dítěte školního věku, Sociální pedagogiku a Úvod do pedagogiky. V období před výzkumem se neúčastnili žádné výuky didaktiky biologie.

Studenti dostali za úkol napsat písemnou reflexi na zadanou videoukázku vyučovací hodiny. Rozsah reflexe nebyl stanoven. Studenti byli požádáni, aby napsali vše, co je zaujalo, nebáli se vyjádřit své názory a snažili se psát celými větami, ne jen heslovitě. Reflexe psali doma a na video se mohli podívat, kolikrát chtěli. Odkaz na video byl studentům zaslán e-mailem, termín odevzdání byl stanoven na čtrnáct dní od zadání. Reflexe byly odevzdávány v elektronické podobě.

Pro výzkum bylo vybráno video Měkkýši dostupné na webových stránkách Metodického portálu RVP ${ }^{1}$, které obsahuje několik dobře zřetelných didakticko-biologických jevi̊ a na jeho začátku je divák seznámen s kontextem hodiny samotnou vyučující. Na videu se stř́idají různé aktivity a probíhají četné interakce vyučující se žáky,

\footnotetext{
${ }^{1}$ Dostupné z http://www.rvp.cz
} 
což poskytuje studentům dostatek př́ležitostí tyto jevy zachytit a uvést v reflexích. Videoukázka obsahovala hodinu biologie ve čtvrtém ročníku šestiletého gymnázia, kde bylo probíráno téma morfologie a životní prostředí měkkýšů. Žáci v ukázce po krátkém opakování učiva pracovali nejprve ve skupinách $\mathrm{s}$ textem $\mathrm{v}$ učebnici a vypisovali z něj informace, které doplňovali do tabulky připravené vyučující. Vypsané informace poté prezentovali svým spolužákům a vybrané pojmy ukazovali na přírodninách. Hodina byla zakončena společným opakování spojeným s promítáním obrázků zástupců měkkýšů.

\subsection{ANALÝZA DAT}

Data z písemných reflexí byla analyzována podle metodiky publikované Sherin a van Es (2009), viz tab. 1. Při výběru kategoriálního systému byly zvažovány různé možnosti popsané v literatuře (Santagata, Zannoni \& Stigler, 2007; Stockero, 2008; Seidel et al., 2011 a další), uvedený systém byl zvolen z důvodu jeho rozšířenosti a možnosti pozdějšího srovnání výsledků s jinými studiemi. Reflexe byly nejprve rozděleny na významové jednotky (zpravidla celé věty; souvětí byla dělena v př́ípadě odlišného zaměření jednotlivých vět) a poté zakódovány podle kategorií uvedených v tab. 1 . Každý výrok byl přiřazen $\mathrm{k}$ jedné kategorií $\mathrm{v}$ každé ze čtyř oblastí. Např. výrok „Hned ze začátku se mi líbí, jak se paní učitelka ptá žáki̊, jaké základní informace o měkkýších si pamatují ze dvou předchozích hodin." byl kódován učitel obor a oborová didaktika - hodnocení - konkrétní; výrok „Žáci si veškeré informace dokázali vyhledat a doplnit sami." byl kódován žák - pedagogika a obecná didaktika - popis - obecný. Obsah kategorií je zřejmý z jejich názvu a nepotřebuje bližší vysvětlení, snad kromě kategorie tvůrce kurikula, kam byly zařazeny výroky týkající se tvůrců vzdělávacích programů, autorů učebnic, tvůrců výukových materiálů, učebních úloh, výukových pomůcek, tematických plánů, témat hodin apod.

Tab. 1: Čtyři oblasti kategorií pro kódování výroků (podle Sherin a van Es, 2009)

\begin{tabular}{l|l}
\hline Oblast & kategorie \\
\hline Aktér & učitel - žák - pozorovatel videa - tvưrce kurikula - jiné \\
\hline Téma & $\begin{array}{l}\text { obor a oborová didaktika - pedagogika a obecná didaktika - } \\
\text { klima tř́dy - ř́zení tř́́dy - jiné }\end{array}$ \\
\hline Př́stup & popis - hodnocení - interpretace - jiné \\
\hline Míra konkrétnosti & konkrétní - obecný \\
\hline
\end{tabular}

Kódování prováděly tři kódující, členky širšího výzkumného týmu, nejprve individuálně. Následně byly jejich kódy porovnány a v případě shody dvou až tří kódů bylo učiněno rozhodnutí pro každou jednotku. V př́ípadě výskytu tří různých kódů u jedné jednotky, což bylo pouze v $0,01 \%$ př́padi̊, se výzkumnice na výsledném kódu společně dohodly. Použitím výše uvedené metodiky byl získán základní přehled o charakteru studentských výroků a jejich četnosti. Data byla analyzována za použití popisné statistiky.

Dále bylo sledováno, které kategorie se ve významových jednotkách vyskytují společně a s jakou četností. Pro tuto analýzu bylo zvoleno třídění podle jednotlivých aktérů a bylo zjištováno, s jakým tématem jsou tito aktéři spojováni a jaký je současně př́stup studentů $\mathrm{k}$ analýze dění uvedených v těchto vybraných výrocích. Pro snadnější vyhodnocování byly nejprve vyloučeny všechny výroky, kde se v kategoriích téma nebo přistup objevil kód jiné. Zásah do datového souboru byl nepatrný, jednalo se jen o dvě položky u aktéra učitel, pět položek u aktéra pozorovatel 
videa a jednu položku u aktéra tvůrce kurikula. Výsledky jsou prezentovány graficky (graf 1-3).

Data vztahující se k oboru a oborové didaktice ve spojení s ostatními kategoriemi byla analyzována následně i kvalitativně s cílem zjistit tematické zaměření těchto výroků. Významové jednotky byly tř́iděny do podkategorií podle publikace Pavlasová et al. (v tisku): (1) metody, formy, postupy a pojetí výuky, (2) cíl výuky, očekávané výstupy, kompetence, obsah výuky, (3) motivace, aktivizace, pozornost, (4) řízení tř́idy (management), (5) didaktické zásady. Navíc byly přidány podkategorie (6) pomůcky a (7) instrukce učitele. Kategorie klima třídy nebyla použita, protože se ve výrocích vůbec nevyskytovala (viz tab. 4). Každá významová jednotka byla přřrazena do jedné podkategorie. Spolu s komentářem uvádíme i jejich četnosti, protože mají určitou vypovídající hodnotu.

\section{VÝSLEDKY}

\subsection{OBLASTI A KATEGORIE VŠímÁNí SI}

Celkem bylo získáno 26 reflexí s rozdílnou délkou textu. Nejkratší obsahovala 506 znaků i s mezerami, nejdelší 3 885. Průměrná délka reflexe byla 1400 znaků i s mezerami, medián 945, směrodatná odchylka 954. Souhrnná délka všech reflexí byla 36403 znaků i s mezerami. Reflexe byly nejprve rozděleny na úseky (významové jednotky) s výpovědní hodnotou vhodnou pro kódování. Nejnižší počet úseků v reflexi byl 6 , nejvyšší počet úseků 59, průměr 19, medián 13, směrodatná odchylka 14 . Celkový počet kódovaných úseků byl 489. Četnost výroků v jednotlivých kategoriích po zakódování metodikou podle Sherin a van Es (2009) je uvedena v tab. 2.

Tab. 2: Četnost výroků v kategoriích podle Sherin a van Es (2009). Celkový počet výroků analyzovaných v každé kategorii je 489. Relativní četnosti jsou zaokrouhleny na dvě desetinná místa

\begin{tabular}{l|c|c}
\hline Oblast/Kategorie & $\begin{array}{c}\text { Četnost výrokù } \\
\text { v kategorii }\end{array}$ & $\begin{array}{c}\text { Rel. četnost výroků } \\
\text { v kategorii }\end{array}$ \\
\hline Aktér & 179 & $36,61 \%$ \\
\hline Učitel & 135 & $27,61 \%$ \\
\hline Žák & 17 & $3,48 \%$ \\
\hline Pozorovatel videa & 76 & $15,54 \%$ \\
\hline Tvůrce kurikula & 82 & $16,77 \%$ \\
\hline Jiné & & \\
\hline Téma & 85 & $17,38 \%$ \\
\hline Obor a oborová didaktika & 302 & $61,76 \%$ \\
\hline Pedagogika a obecná didaktika & 54 & $11,04 \%$ \\
\hline Klima třídy & 21 & $4,29 \%$ \\
\hline Rízení tř́́dy & 27 & $5,52 \%$ \\
\hline Jiné & & $34,15 \%$ \\
\hline Př́stup & 167 & $44,58 \%$ \\
\hline Popis & 218 & $16,56 \%$ \\
\hline Hodnocení & 81 & $4,70 \%$ \\
\hline Interpretace & 23 & $7,98 \%$ \\
\hline Jiné & \multicolumn{2}{|c}{} \\
\hline Míra konkrétnosti & 39 & $92,02 \%$ \\
\hline Konkrétní & 450 & \\
\hline Obecný & \multicolumn{2}{|c}{$\%$} \\
\hline
\end{tabular}


Z tabulky 2 vyplývá, že si studenti nejvíce ze všech aktérů výuky všímají učitele a hned potom žáka (výzkumná otázka 1). Naproti tomu v minimální míře popisují dění ve výuce $\mathrm{z}$ hlediska toho, jak by výuky vedli oni sami v roli učitele (kategorie pozorovatel videa). Téma komentářů je $\mathrm{v}$ převážné většině $\mathrm{z}$ oblasti pedagogiky a obecné didaktiky oproti oboru a oborové didaktice, které jsou komentovány v mnohem menší míře. Klima třídy a řízení tř̌idy se zdá být na okraji zájmu studenti̊. Př́stup, jakým způsobem jsou výroky uváděny, je převážně hodnotící, kdy student uvádí, co mu ve výuce líbí nebo nelíbí, ovšem většinou bez zdůvodnění. V menší míře se vyskytují výroky popisné obsahující pouhou rekapitulaci událostí. Interpretace vyžadující hlubší uvažování o pozorovaných jevech byly zaznamenány jen v malém procentu případů. Téměř všechny výroky se týkají obecných činností ve výuce, konkrétní události z vyučovací hodiny, učivo, výroky aktérů jsou uvedeny jen ojediněle.

\subsection{KATEGORIE AKTÉR V ŠIRŠÍCH SOUVISLOSTECH}

Podrobnější analýza vyžadovala zjištění, s jakou četností se vyskytovaly vybrané kategorie ve výrocích společně (výzkumná otázka 2). Zvoleno bylo třídění podle jednotlivých aktérů a bylo zjištováno, s jakým tématem jsou tito aktéŕi spojováni a jaký je přistup studentů $\mathrm{k}$ analýze dění uvedených v těchto vybraných výrocích. Výsledky jsou uvedeny $\mathrm{v}$ grafech $1-3$.

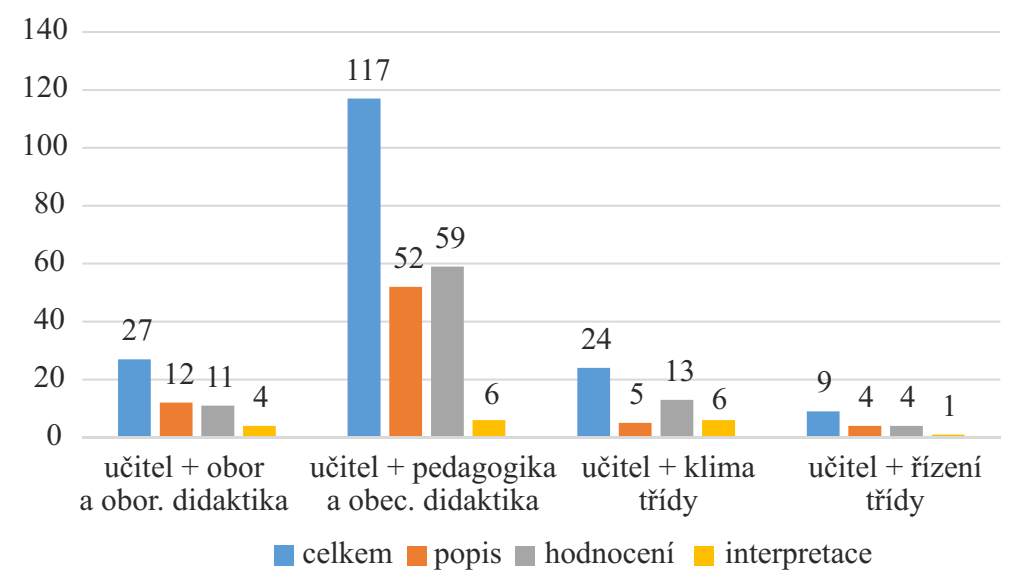

Graf 1: Četnost výskytu významových jednotek ve výrocích uvedených v souvislosti s učitelem $(n=177)$

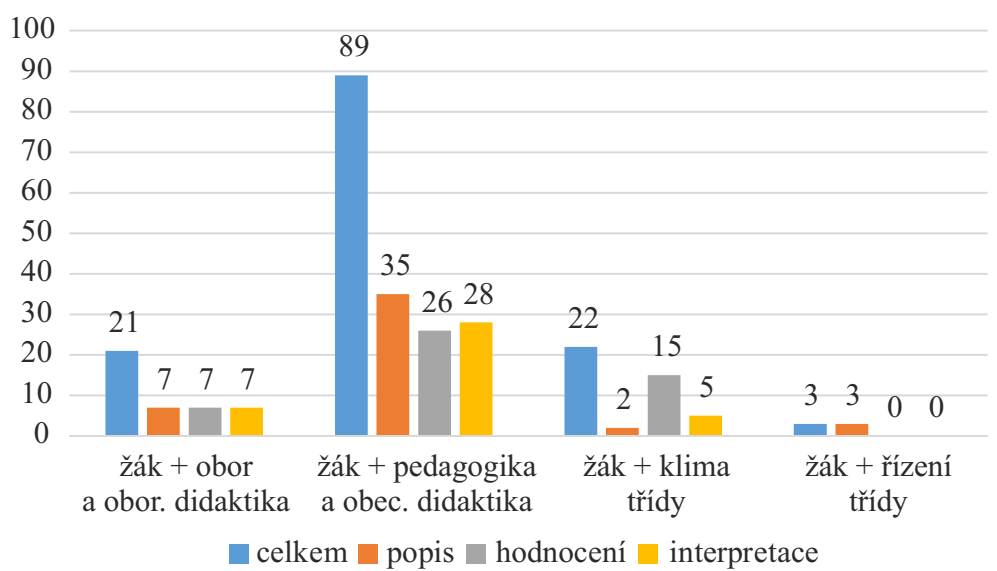

Graf 2: Cetnost výskytu významových jednotek ve výrocích uvedených v souvislosti se žákem $(n=135)$ 


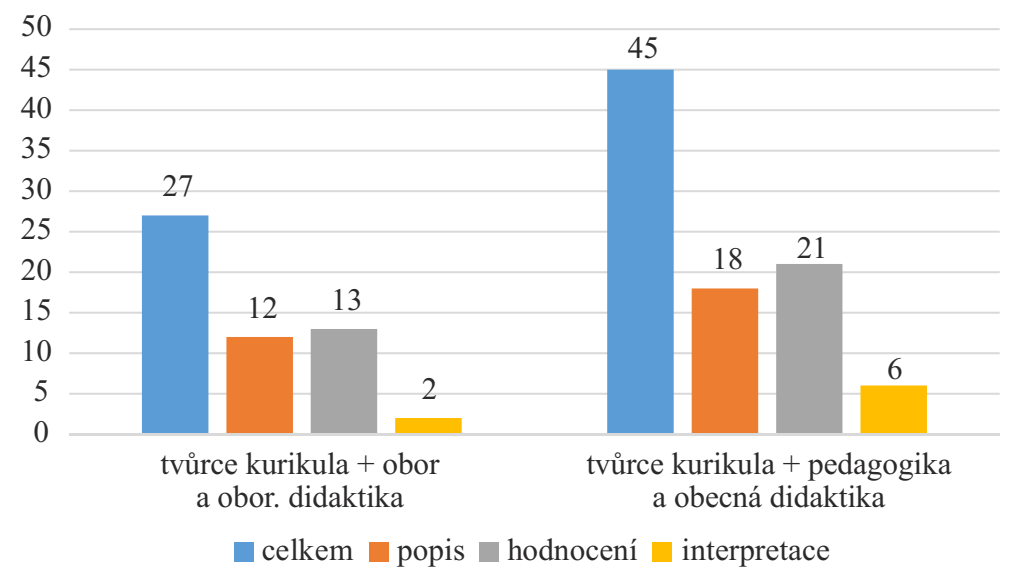

Graf 3: Cetnost výskytu významových jednotek ve výrocích uvedených v souvislosti s tvưrcem kurikula $(n=72)$. Tři prrípady týkající se tvưrce kurikula a řízení tř́ídy nejsou $\mathrm{v}$ grafu zobrazeny

Výroky uvedené v souvislosti s učitelem (graf 1) se tematicky týkají převážně pedagogiky a obecné didaktiky $(66,10 \%)$. Toto platí i pro výroky uvedené v souvislosti se žákem (graf 2;65,93 \%) a tvůrcem kurikula (graf 3;62,50 \%). Komentáře studentů jsou v tomto ohledu vyrovnané a nenalézáme zde rozdílný příspěvek k celkovému relativnímu počtu výroků v této kategorii u žádného aktéra. Mnohem méně si studenti všímají ve spojení s učitelem, žákem i tvůrcem kurikula oborových a oborově didaktických jevů (grafy 1-3; 15,25 \% versus 15,56 \% a 37,50 \%), i když tvůrce kurikula je zmiňován výrazně častěji než obě dvě další kategorie (viz dále tab. 3 ). Klima třídy se ve výrocích vyskytuje s podobnou četností ve spojení s učitelem i žákem. Řízení třídy je zmiňováno minoritně. Tvůrce kurikula se ve spojení s klimatem třídy nevyskytoval ani $\mathrm{v}$ jednom výroku a ve spojení s řízením třídy jen ve třech př́padech (tyto údaje proto neuvádíme v grafu ani je dále nekomentujeme). Kategorie pozorovatel videa byla zastoupena nejméně z všech kategorií jak absolutně, tak i ve spojení s dalšími aktéry. Byla identifikována pouze u 17 významových jednotek ve všech reflexích (tab. 2), což je velmi malý počet pro vyvozování jakýchkoliv závěrů. Nebudeme se jí proto dále zabývat.

Přístup k uvažování o pozorovaných jevech (výzkumná otázka 2) ve spojení se žákem je z hlediska četností v podstatě stejný u všech tří sledovaných kategorií (popis $34,81 \%$, hodnocení 35,56 \%, interpretace 29,63\%). To je odlišné od př́stupu zjištěného u výroků ve spojení s učitelem i tvůrcem kurikula, kdy převažuje hodnocení $(49,15 \%$, resp. 47,22 \%), následováno popisem $(41,24 \%$, resp. 41,67\%) a velmi málo zastoupenou interpretací $(9,60 \%$, resp. 11,11 \%). Zaznamenáváme zde zřetelný posun od popisu a hodnocení k interpretaci, tedy hlubšímu uvažování, u výroků spojených se žákem („Z těchto zápisků se pak žáci snáze budou připravovat na přiští zkoušení, nebot si vědomosti sami prožili v dané hodině zážitkovou metodou.“, „Ale studenti si z pár řádků v učebnici a tabulky, kterou někam založí, nebudou mnoho pamatovat.“, „Žáci nebo studenti, pokud mají zadanou práci, tak se nesoustředí na výklad pedagoga.“) oproti výrokům spojeným s učitelem („Práci by urychlilo, kdyby jim toto oznámila už při začátku sjednocování informací na tabuli.“, „Vyučující je nutí myslet a propojovat si informace, poukazuje i na mediální zprávy.", „Myslím, že by měla nechat otevřenou debatu nad věcmi, které nejsou zcela jasné.“). U výroků spojených s učitelem převažuje naopak popis ( „Paní učitelka využila dataprojektor a nejen k opakování ale i k výuce.") a hodnocení, které není podpořeno argumenty („Líbilo se mi, jak pojala výklad.“, „Podle mého názoru není na místě, aby paní učitelka pořád opakovala slovo svižně."). 


\subsection{KATEGORIE OBOR A OBOROVÁ DIDAKTIKA V ŠIRŠÍCH SOUVISLOSTECH}

Podrobněji jsme se následně věnovali tematickému zaměření výroků v kategorii obor a oborová didaktika uvedených ve spojení s aktéry učitel, žák a tvůrce kurikula (výzkumná otázka 3). Učitel a žák byl komentován studenty učitelství v souvislosti s oborem a oborovou didaktikou zhruba se stejnou relativní četností. Na rozdíl od kategorie tvůrce kurikula, kde je relativní podíl komentářů výrazně vyšší (viz tab. 3), což vyplývá ze samotné podstaty kategorie (viz kap. 2.2).

Tab. 3: Četnost výskytu významových jednotek ve výrocích týkajících se oboru a oborové didaktiky ve spojení s kategorií učitel, žák a tvưrce kurikula $(n=75)$

\begin{tabular}{l|c|c}
\hline $\begin{array}{c}\text { Výroky v kategorii } \\
\text { obor a oborová didaktika } \\
\text { uvedené v souvislosti } \\
\text { s kategorií... }\end{array}$ & $\begin{array}{c}\text { Cetnost/celkem } \\
\text { jednotek v kategorii }\end{array}$ & Relativní četnost \% \\
\hline Učitel & $27 / 177$ & $15,25 \%$ \\
\hline Źák & $21 / 135$ & $15,56 \%$ \\
\hline Tvưrce kurikula & $27 / 72$ & $37,50 \%$ \\
\hline
\end{tabular}

Četnost výskytu významových jednotek v identifikovaných podkategoriích kategorie obor a oborová didaktika uvedená ve spojení s kategorí učitel, žák, pozorovatel videa a tvưrce kurikula je uveden $\mathrm{v}$ tab. 4 . Není zohledněn přístup studenta $\mathrm{k}$ analýze výuky, tedy jestli studenti výuku popisují, hodnotí nebo interpretují, ale pouze tematické zaměření významové jednotky. Jako př́ílad uvádíme měnící se zaměření výroků u podkategorie metody, formy, postupy a pojetí výuky: výrok ve spojení s učitelem („Vyučující se snažila popsat a laserovým ukazovátkem ukazovala všechny podstatné typické znaky u jednotlivých zástupců měkkýšů."), se žákem („Studenti společně zopakují poznatky z minulé hodiny - shrnutí základních znaků měkkýšů a jejich taxonomické zařazení.“) a s tvưrcem kurikula („Dále se mi líbilo využití množství názorných exponátů i spojení s projekcí diapozitivů.“).

Tab. 4: Četnost výskytu významových jednotek v identifikovaných podkategoriích kategorie obor a oborová didaktika uvedená ve spojení s kategorií učitel, žák, pozorovatel videa a tvůrce kurikula $(n=75)$

\begin{tabular}{|c|c|c|c|}
\hline Podkategorie & $\begin{array}{c}\text { Obor a obor. } \\
\text { didaktika } \\
\text { ve spojení } \\
\text { s učitelem } \\
n=27\end{array}$ & $\begin{array}{c}\text { Obor a obor. } \\
\text { didaktika } \\
\text { ve spojení } \\
\text { s žákem } \\
n=21\end{array}$ & $\begin{array}{c}\text { Obor a obor. } \\
\text { didaktika } \\
\text { ve spojení } \\
\text { s tvurcem } \\
\text { kurikula } \\
n=27\end{array}$ \\
\hline Metody, formy, postupy a pojetí výuky & $9 / 33,33 \%$ & $9 / 42,86 \%$ & $14 / 51,85 \%$ \\
\hline $\begin{array}{l}\text { Cíl výuky, očekávané výstupy, } \\
\text { kompetence, obsah výuky }\end{array}$ & $9 / 33,33 \%$ & $9 / 42,86 \%$ & $5 / 18,52 \%$ \\
\hline Motivace, aktivizace, pozornost & $2 / 7,40 \%$ & - & - \\
\hline Řízení třídy (management) & - & $1 / 4,76 \%$ & - \\
\hline Didaktické zásady & $4 / 14,81 \%$ & - & - \\
\hline Pomůcky & $1 / 3,70 \%$ & $1 / 4,76 \%$ & $7 / 25,93 \%$ \\
\hline $\begin{array}{l}\text { Instrukce učitele } \\
\end{array}$ & $1 / 3,70 \%$ & - & - \\
\hline Jiné & $1 / 3,70 \%$ & $1 / 4,76 \%$ & $1 / 3,70 \%$ \\
\hline
\end{tabular}


Celkově se s největší četností objevují výroky komentující metody, formy, postupy a pojetí výuky. Jejich obsah je převážně popisný nebo hodnotící („Výklad byl doplňován obrazovými materiály a vzorky měkkýšuo.", „Přínosná byla demonstrace některých plžů, mlžů a hlavonožců."). Vyskytly se i interpretační výroky s náznakem opory o teorii, ve kterých se studenti hlouběji zamýšleli nad vhodností použitých metod a jejich dopadem na znalosti žáka („Je sice hezké, když žákům něco ukážeme v knížce, či promítneme na plátně, ale určitě je mnohem lepší, když si to opět žáci mohou osahat a hezky na nich mohou popsat jejich morfologické znaky.", „Ovšem přišlo mi, že pořádně si demonstrované měkkýše mohli prohlédnout jen studenti, kteří je měli v úkolu zpracovat.“, „Demonstrace materiálu (s výjimkou lastury hřebenatky a sépiové kosti) se odbývá prohlášením: máte tady schránky.“).

Poměrně značná pozornost je studenty věnována cílům výuky („Výuka se zaměřovala na morfologii měkkýšů.“), očekávaným výstupům („Žáci nejsou schopni tyto zástupce rozpoznat na fotografích, dokonce ani ti, kteří je měli prezentovat."), kompetencím a obsahu výuky („Podle mého názoru se jedná o složitější typ látky biologie živočichů.“, „Vyučující odkazuje na aktuální regionální medii ššřenou zajímavost vztahující k tématu - levotočivý hlemýžd'“").

V kategorii obor a oborová didaktika uváděné ve spojení s kategorií tvůrce kurikula se komentáře nejčastěji zabývaly pomůckami. Výroky se týkají převážně použité učebnice („A nepřekvapilo mě, že zvolila Biologii pro gymnázia.“) a dalších pomůcek („Suprová je i tabulka, do které si žáci vpisují jednotlivé morfologické znaky měkkýšů. "). Nekomentují je ovšem v souvislosti s činností učitele nebo žáka, jen si všímají jejich přítomnosti ve výuce. Dále je zajímavé, že jen velmi málo komentují samotné př́rodniny, které byly dominantní pomůckou ve sledované ukázce výuky, a nešlo je přehlédnout. Použivání přírodnin ve výuce bylo konstatováno pouze ve dvou výrocích studentů („V ukázce o měkkýších mají sice při hodinách přírodopisu horší technické vybavení, ale o to více pracují žáci s trvalými exponáty.“, „Učitelka má hodinu velmi dobře připravenou - preparáty, tabulky, nápisy na tabuli apod.“) bez vyjádření k jejich volbě, množství, popisu apod.

V kategorii obor a oborová didaktika se v souvislosti s učitelem objevují čtyři komentáře, které můžeme považovat za úvahy obsahující náznaky intuitivního povědomí o didaktických zásadách. Můžeme zde identifikovat zásadu vědeckosti ( „Učitelka je nutí používat správnou terminologii.“, „Nedopouští se faktických chyb, pouze určitých nepřesností a neodbornosti.“, „Sem tam se paní profesorka dopustila chyb, např. velevrub se neodlišuje přítomností vrubu, ale počtem zámků.") a zásadu propojení teorie s praxí a školy se životem („Učitelka propojuje informace o prezentovaných zástupcích s žákům známými skutečnostmi a zkušenostmi z běžného života - pojídání ústřic.").

Zajímavé jsou př́pady, kdy stejné momenty ve výuce studenti komentují odlišným způsobem. Vypovídá to o jejich odlišném nazírání na výukovou situaci, kdy ji např. odlišně hodnotí ( PPř́nosná byla demonstrace některých plžů, mlžů a hlavonožců." versus „Skupiny plžů, mlžů a hlavonožců neměli dostatek času, aby si válce nebo schránky důkladně prohlédly.").

Pokud bychom měli zmínit, co nám ve výpovědích studentů chybělo a čemu nevěnují v souvislosti s oborem pozornost, tak by to byly odborné chyby a nepřesnosti $\mathrm{v}$ terminologii učitele. Těch se ve videu několik vyskytlo, ale studenti je přešli, až na výjimky, bez povšimnutí. 


\section{Diskuse}

\subsection{VŠÍMÁNÍ SI A PŘÍSTUP STUDENTU゚ K VIDĚNÉMU}

Struktura všímání si je obdobná jako ve výzkumech Sonmez a Hacverdi-Can (2012). I v našem výzkumu si studenti učitelství všímali více učitele než žáka a pedagogických a obecně didaktických jevů na úkor jevů zaměřených na obor a oborovou didaktiku (výzkumná otázka 1). Zaznamenali jsme soulad i s výsledky uvedenými Stehlíkovou (2010) a Vondrovou a Žalskou (2015), které zkoumaly studenty učitelství matematiky. Všímání si zaměřené více na učitele a obecně pedagogické jevy než na žáka a obsah výuky uvádějí i výzkumy Santagata, Zannoni a Stigler (2007) a Mitchell a Marin (2015) u studentů učitelství matematiky.

Studenti na začátku učitelského studia tedy uvažují o výuce zejména v obecné rovině a méně domýšlejí pozorované jevy až do úrovně biologie jako oboru a didaktiky biologie. Z hlediska Shulmanova pojetí znalostní báze učitele (Shulman, 1987) používají především znalosti obecně pedagogické (general pedagogical knowledge) a méně znalosti samotného obsahu (content knowledge) a didaktické znalosti obsahu (pedagogical content knowledge). Otázkou je, zda jim v uvažování nebrání přeci jen menší znalost oboru, než jakou budou mít na konci učitelského studia (tedy po dalších dvou letech), a také zda se po absolvování kurzů oborové didaktiky tento podíl pedagogiky a obecné didaktiky versus oboru a oborové didaktiky bude měnit ve prospěch právě oborové didaktiky. Na zmíněné otázky snad poskytnou odpověd' navazující výzkumy autorky.

Komentáře vztahující se $\mathrm{k}$ žákovi byly přítomny sice $\mathrm{v}$ menší míře než komentáře učitele, nicméně $\mathrm{v}$ počtu, který svědčí o přemýšlení o výuce $\mathrm{z}$ obou stran, jak ze strany učitele, tak ze strany žáka. U studentů učitelství 1. stupně zaznamenáváme $\mathrm{v}$ některých výzkumech opačný poměr, kdy je student učitelství více zaměřen na žáka (Pavlasová et al., v tisku; Uličná, 2017). Tento jev patrně vypovídá o tom, že námi zkoumaní učitelé biologie 2. stupně ZŠ a SS̆ jsou patrně více orientováni na výuku oboru než obecně na práci s dítětem.

V komentářích se nejméně vyskytuje kategorie pozorovatel videa. To může být svým způsobem pochopitelné, studenti jsou teprve na začátku učitelského studia a o výuce patrně ještě neuvažují jako o něčem, co budou sami provádět, a nezamýšlejí se nad tím, jak výuku vést jinak. Berou patrně učitele na videu jako určitý profesní vzor, výuku popisují a ve značné míře hodnotí, ale nepouštějí se do interpretací ani do uvažování, co dělat jinak nebo proč to dělat stejně jako učitel na videu.

Př́istup studentů $\mathrm{k}$ analýze výuky byl převážně hodnotící nebo popisný. Interpretace, kdy student opírá svoje tvrzení o teorii, vysvětluje je, navrhuje alterace nebo predikuje důsledky výuky vzhledem $\mathrm{k}$ budoucímu rozvoji žáků, byly zaznamenány jen v nízkém počtu případů (srov. Pavlasová et al., v tisku). Tato zjištění nejsou překvapivá, protože se jednalo o studenty na začátku jejich př́ípravného vzdělávání, u kterých schopnost intepretace dění ve výuce není ještě plně rozvinuta, nejsou vybaveni teoretickými základy a nemají dostatek zkušeností s vlastní výukou. Výsledky otevírají zároveň prostor pro zaměření úloh v didaktických kurzech a jejich zacílení na rozvoj uvažování založeného na znalostech. Ovšem některé výzkumy ukazují (např. Stürmer, Seidel \& Holzberger, 2016), že vstupní dovednosti studentů na začátku kurzů i možnost jejich ovlivnění jsou individuální a mezi studenty existují rozdíly. Např́íklad zejména dovednost predikce je obtížněji ovlivnitelná a míra růstu dovedností studentů po intervenci klesá s vyššími vstupními dovednostmi (tamtéž). 
Komentáře studentů byly převážně obecné, jen v malé míře si všímali konkrétních (specifických) událostí v hodině (konkrétních výroků učitele nebo žáka, zadání konkrétních učebních úloh apod.), obdobně jako v jiných výzkumech (např. Simpson, Vondrová \& Žalská, 2017).

\subsection{KATEGORIE AKTÉR VE SPOJENí S OSTATNÍMI KATEGORIEMI}

Při analýze společného výskytu kategorií bylo zjištěno, že se kategorie pedagogika a obecná didaktika vyskytuje s největší četností ve spojení se všemi uvažovanými aktéry (učitel, žák i tvůrce kurikula), což jenom potvrzuje celkové výsledky komentované $\mathrm{v}$ kapitole 4.1. Všechny kategorie tedy přispívají rovnoměrně $\mathrm{k}$ celkovému výsledku. U všech zmíněných kategorií byl také potvrzen mnohem menší výskyt výroků vztažených k oboru a oborové didaktice (výzkumná otázka 2). Toto je zajímavé v porovnání se studí́ Simpsona, Vondrové a Žalské (2017), ve které naopak jimi zkoumaní studenti učitelství matematiky komentovali více matematický obsah než obecné pedagogické jevy (autoři využívali stejný kategoriální systém jako v našem výzkumu). Všímání si oboru a specifických didakticko-biologických jevů považujeme při přípravě studenta učitelství biologie za klíčové, proto mu byla v tomto výzkumu věnována zvláštní pozornost. Zejména proto, že ve výzkumných studiích nepanuje shoda o podílu pozornosti, kterou studenti oboru a oborové didaktice věnují na úkor pedagogiky a obecné didaktiky. Z tohoto důvodu byly výroky dále analyzovány s cílem zjistit jemné nuance $\mathrm{v}$ jejich zaměření (viz kapitola 3.3 a dále).

Přístup k uvažování o pozorovaných jevech je z hlediska četností v podstatě stejný u všech tři sledovaných kategorií (pedagogika a obecná didaktika, obor a oborová didaktika, klima třídy) ve spojení s kategorií žák (výzkumná otázka 2). Rovnoměrně zde zaznamenáváme popisný, hodnotící i interpretační př́stup. K podobným výsledkům dospěla Uličná (2017) u studentů učitelství anglického jazyka pro 2. a 3. stupeň (její výsledky se týkají kategorie žák jako celku). Je to ovšem odlišné od př́istupu zjištěného u kategorie učitel (ale i tvůrce kurikula), kde převažuje hodnocení následované popisem situace. Interpretace jsou zastoupeny pouze minoritně. Podobně malé zastoupení interpretací ve spojení s učitelem uvádějí i Uličná, Stará a Novotná (2017) u studentů učitelství 1. stupně ZŠ. Jedním z důvodů vysvětlující tento rozdíl může být fakt, že se student učitelství lépe vcítí do osoby žáka než do osoby učitele, protože se do jeho komentářu mohou promítnout zkušenosti z jeho vlastní školní docházky. Tím si můžeme vysvětlit podstatně vyšší celkový počet interpretačních výroků a posun od popisu a hodnocení směrem $\mathrm{k}$ interpretaci u jevů spojených $\mathrm{s}$ žákem. Naopak převažující popis a hodnocení u učitele v porovnání se žákem může být způsobeno tím, že s profesí učitele se student ještě plně neidentifikuje, nedokáže hlouběji uvažovat o pozorovaných jevech a o prřćčinách jednání učitele na videu. Je schopen pouze určité události popsat a posoudit, zda se mu líbí nebo ne, což opět připomíná spíše „pohled žáka hodnotícího svého učitele“. Určitě bude zajímavé sledovat, zda se tento poměr $\mathrm{v}$ přístupu k pozorovaným jevům bude $\mathrm{u}$ studentů měnit $\mathrm{v}$ průběhu studia, případně zda bude záviset na délce praxe u učitelů již působících na školách.

\subsection{KATEGORIE OBOR A OBOROVÁ DIDAKTIKA}

Stehlíková (2010) zjistila u studentů učitelství a učitelů matematiky, že jen v malé míře komentovali specifické didakticko-matematické jevy. Následně to bylo potvrzeno i ve studii Vondrové a Žalské (2015). Ke stejným výsledkům jsme dospěli 
i v našem výzkumu. Vzhledem k tomu, že porozumění oborově didaktickým jevům je důležitou součástí didaktické znalosti obsahu učitele (viz Shulman, 1987), zaměřili jsme další výzkum právě na obor a oborovou didaktiku a snažili jsme se zjistit tematické zaměření oborových a oborově-didaktických výroků (viz tab. 4, výzkumná otázka 3).

Stehlíková (2010) dále uvádí, že studenti učitelství a učitelé matematiky věnovali v komentářích $\mathrm{k}$ hodině matematiky značnou pozornost aktivizaci žáků ve výuce. Studenti učitelství biologie se na začátku svého studia tomuto tématu nevěnovali téměř vůbec (zaznamenali jsme jen dva komentáře s tímto obsahem týkající se oboru a oborové didaktiky v souvislosti s učitelem).

Santagata, Zannoni a Stigler (2007) uvádějí, že si studenti učitelství matematiky na počátku kurzu zaměřeného na rozvoj všímání si více všímají obecně didaktických jevů (což je též v souladu s našimi výsledky) a neuvádějí př́liš často komentáře k obsahu výuky, a pokud je uvádějí, tak v souvislosti s činností učitele. Podle našich zjištění je naopak obsah výuky komentován s vyšší relativní četností v souvislosti se žákem (tab. 4), i když četnost komentářo týkajících se obsahu výuky a učitele není rozhodně zanedbatelný. Tento jev bude určitě zajímavé sledovat u studentů učitelství biologie na konci studia.

V kategorii tvůrce kurikula ve spojení s oborem a oborovou didaktikou (tab. 4) studenti nejčastěji zmiňovali použité pomůcky, což je na jednu stranu pochopitelné, protože to vyplývá ze samé podstaty kategorie a charakteru viděné hodiny. Pomůcky ovšem nebyly dávány do souvislosti s činností učitele nebo žáka, nebyl komentován jejich výběr, spojitost s obsahem učiva a cílem výuky. Podobně laděná vyjádření bychom očekávali zejména u přírodnin, kterých byla ve výuce použita celá řada. Zde vidíme další důležitý úkol/prostor pro oborovou didaktiku, protože použití přírodnin je vzhledem k dodržování didaktické zásady názornosti v biologii klíčové. Totéž se týká i zařazování úloh cílených na analýzu odborného obsahu výuky, kde jsou značné rezervy studentů v identifikování chyb nebo terminologických nepřesností učitele.

Uvedené výsledky mohou poskytnout oporu vzdělavatelům budoucích učitelů biologie, protože dávají obraz o představách studentů o výuce biologie na př́kladu konkrétního tématu výuky. Tento př́stup k výzkumu je obecně doporučován (viz Van Dijk \& Kattmann, 2007).

\subsection{OMEZENÍ VÝZKUMU}

Výsledky byly získány u omezeného počtu studentů jednoho ročníku (akademický rok 2015/2016), což bylo dáno počtem přijatých do studia a dobrovolnou účastí ve výzkumu. I když studenti nebyli nijak předem vybíráni, při zobecňování výsledků je nutná opatrnost. Pro základní analýzu byl po zvážení zvolen jeden z literárně popsaných kategoriálních systémů (Sherin \& van Es, 2009), což bylo výhodné při srovnávání výsledků, ale mohlo také způsobit opominutí některého jevu, na který se tento systém primárně nezaměřuje. Samotné zkoumání volných reflexí studentů může mít také své úskalí a poskytovat poněkud jiné výsledky, než výzkumy prováděné pomocí elektronických výzkumných nástrojů (používaných např. ve výzkumu Blomberg, Stürmer \& Seidel, 2011), kde jsou studenti na některé odpovědi přímo naváděni otázkami. V neposlední řadě může být všímání si ovlivněno volbou videa. Abychom tuto možnost pokud možno eliminovali, sledovali studenti výuku tématu v souladu se svojí studovanou aprobací včetně př́slušné věkové skupiny žáků. Výuka obsahovala prvky typické pro výuku biologie (př. demonstrace, pozorování a určování přrírodnin) a množství různých činností a interakcí. 


\section{ZÁvĚR}

Provedený výzkum byl zacílen na zjištování dovedností v oblasti profesního vidění u studentů učitelství biologie pro 2. a 3. stupeň. Bylo zjištěno, že studenti svoji pozornost zaměřují především na učitele a na pedagogické a obecně didaktické jevy. Jejich komentáře jsou z velké části popisné nebo hodnotící. V mnohem menší míre jsme zaznamenali výroky vztahující ke k oboru a oborové didaktice a výroky interpretující dění ve výuce. Další analýzy ukázaly, že výroky uváděné ve spojení se žákem jsou ve větší míře interpretovány než výroky spojené s učitelem, kde převažuje popis a hodnocení. Podrobnější analýza oborových a oborově didaktických komentářu ukázala jejich tematickou orientaci na dvě širší oblasti: (1) metody, formy, postupy a pojetí výuky a (2) cíl výuky, očekávané výstupy, kompetence, obsah výuky. Mezi opomíjená témata patřily například pomůcky, motivace, aktivizace a pozornost žáků, instrukce učitele. Jen ojediněle studenti komentovali odborné chyby a terminologické nepřesnosti učitele.

Tato zjištění poskytují důležité informace garantům kurzů didaktiky biologie: 1. o prekoncepcích studentů učitelství biologie, které mohou u svých studentů očekávat; 2. o oblastech, které je potřeba rozvíjet a na které by mohly být zaměřeny intervence $\mathrm{v}$ rámci didaktických kurzů; 3. o fenoménu profesního vidění a jeho zakotvení ve výzkumu i vzdělávací praxi. Výzkum profesního vidění učitelů biologie by měl být úzce navázán nejen na přípravu studentů učitelství, ale i další vzdělávání učitelů. V českém prostředí nabízí množství možností zjištování výchozích stavů dovedností účastníků výzkumů, navrhování a ověřování intervenčních postupů a zjištování proměny úrovně jednotlivých složek profesního vidění v průběhu studia učitelů nebo v průběhu jejich vlastní výukové praxe po absolvování studia. Studenti účastnící se představeného výzkumu budou dále sledováni a bude zjištóován jejich posun na konci učitelského studia, což přispěje k vyhodnocení efektivity současné koncepce vzdělávání učitelů biologie na Pedagogické fakultě Univerzity Karlovy, ale zároveň poskytne i obecnější informace pro ostatní vzdělavatele učitelů.

\section{PoDĚKOVÁNí}

Výzkum byl podpořen programem Progres Q17 Příprava učitele a učitelská profese v kontextu vědy a výzkumu. Mé poděkování patří doc. RNDr. Nadě Vondrové, Ph.D., za cenné připomínky, které mi v průběhu psaní článku poskytla, a PhDr. Janě Staré, Ph.D., a PhDr. Kláře Uličné, Ph.D., za pomoc při kódování.

\section{LITERATURA}

Blomberg, G., Stürmer, K. \& Seidel, T. (2011). How pre-service teachers observe teaching on video: Effects of viewers' teaching subjects and the subject of the video. Teaching and Teacher Education, 27(7), 1131-1140.

Goodwin, C. (1994). Professional vision. American anthropologist, 96(3), 606-633.

Janík, T. \& Seidel, T. (Eds.). (2009). The power of video studies in investigating teaching and learning in the classroom. New York: Waxman.

Ling Wong, S., Wai Yung, B. H., Cheng, M. W., Lam, K. L. \& Hodson, D. (2006). Setting the stage for developing pre-service teachers' conceptions of good science teaching: the role of classroom videos. International Journal of Science Education, 28(1), 1-24. 
Martin, S. N. \& Siry, C. (2012). Using video in science teacher education: An analysis of the utilization of video-based media by teacher educators and researchers. In B. Fraser, K. Tobin, C. McRobbie (Eds.), Second International Handbook of Science Education (417-433). Springer International Handbooks of Education, vol 24. Springer, Dordrecht.

McConnell, T. J., Lundeberg, M. A., Koehler, M. J., Urban-Lurain, M., Zhang, T., Mikeska, J. \& Eberhardt, J. (2008, January). Video-based teacher reflection-What is the real effect on reflections of inservice teachers. Příspěvek prezentovaný na konferenci International Conference of the Association of Science Teacher Educators, Saint Louis, USA.

Minaříková, E. \& Janík, T. (2012). Profesní vidění učitelů: od hledání pojmu k možnostem jeho uchopení. Pedagogická orientace, 22(2), 181-204.

Minaříková, E., Píšová, M., Janík, T. \& Uličná, K. (2015). Video Clubs: EFL teachers' selective attention before and after. Orbis Scholae, 9(2), 55-75.

Mitchell, R. N. \& Marin, K. A. (2015). Examining the use of a structured analysis framework to support prospective teacher noticing. Journal of Mathematics Teacher Education, 18(6), 551-575.

Pavlasová, L., Stará, J., Vondrová, N., Novotná, M., Robová, J. \& Uličná, K. (v tisku). Výběrové zaměření pozornosti u studentů učitelství a povaha jejich interpretací.

Pedagogika, 68(1).

Roth, K. J., Garnier, H.E., Chen, C., Lemmens, M., Schwille, K. \& Wickler, N. I. (2011). Videobased lesson analysis: Effective science PD for teacher and student learning. Journal of Research in Science Teaching, 48(2), 117-148.

Santagata, R., Zannoni, C. \& Stigler, J. W. (2007). The role of lesson analysis in pre-service teacher education: An empirical investigation of teacher learning from a virtual video-based field experience. Journal of mathematics teacher education, 10(2), $123-140$.

Seidel, T., Stürmer, K., Blomberg, G., Kobarg, M. \& Schwindt, K. (2011). Teacher learning from analysis of videotaped classroom situations: Does it make a difference whether teachers observe their own teaching or that of others? Teaching and teacher education, 27(2), 259-267.

Sherin, M. G. \& Han, S. Y. (2004). Teacher learning in the context of a video club. Teacher and Teacher Education, 20(2), 163-183.

Sherin, M. G. \& van Es, E. A. (2005). Using video to support teachers' ability to notice classroom interactions. Journal of technology and teacher education, 13(3), 475-491.

Sherin, M. G. \& van Es, E. A. (2009). Effects of video club participation on teachers' professional vision, Journal of Teacher Education, 60(1), 20-37.

Shulman, L. (1987). Knowledge and teaching: Foundations of the new reform. Harvard educational review, 57(1), 1-23.

Simpson, A., Vondrová, N. \& Žalská, J. (2017). Sources of shifts in pre-service teachers' patterns of attention: the roles of teaching experience and of observational experience. Journal of Mathematics Teacher Education. Advanced online publication. DOI: 10.1007/s10857-017-9370-6

Sonmez, D. \& Hakverdi-Can, M. (2012). Videos as an instructional tool in pre-service science teacher education. Egitim Arastirmalari-Eurasian Journal of Educational Research, 46, 141-158. 
Steffensky, M., Gold, B., Holdynski, M. \& Möller, K. (2015). Professional vision of classroom management and learning support in science classrooms - Does professional vision differ across general and content-specific classroom interactions? International Journal of Science and Mathematics Education, 13(2), 351-368.

Stehlíková, N. (2010). Interpretace některých didakticko-matematických jevů u studentů učitelství a učitelů matematiky. Pedagogika, 60(3-4), 303-313.

Stürmer, K., Seidel, T. \& Holzberger, D. (2016). Intra-individual differences in developing professional vision: preservice teachers' changes in the course of an innovative teacher education program. Instructional Science, 44(3), 293-309.

Stockero, S. L. (2008). Using a video-based curriculum to develop a reflective stance in prospective mathematics teachers. Journal of Mathematics Teacher Education, 11(5), 373-394.

Svatoš, T. (2013). A student teacher on the pathway to teaching profession: Reviewing research and proposing a model. Pedagogická orientace, 23(6), 786-809.

Syslová, Z. (2016). Rozvoj profesního vidění studentů oboru Učitelství pro mateřské školy. Pedagogika, 66(4), 462-476.

Talanquer, V., Tomanek, D. \& Novodvorsky, I. (2013). Assessing students' understanding of inquiry: What do prospective science teachers notice? Journal of Research in Science Teaching, 50(2), 189-208.

Uličná, K. (2017). To see or not to see: Profesní vidění budoucích učitelů anglického jazyka a budoucích učitelů pro 1. stupeň se specializací na anglický jazyk. Pedagogická orientace, $27(1), 81-103$.

Uličná, K., Stará, J. \& Novotná, M. (2017). Teacher in the eyes of future primary school teachers. Proceedings of the 14th International Conference Efficiency and Responsibility in Education (490-497). Prague: Czech University of Life Sciences.

Van Dijk, E. M. \& Kattmann, U. (2007). A research model for the study of science teachers' PCK and improving teacher education. Teaching and Teacher Education, 23(6), $885-897$.

Vondrová, N., Robová, J. \& Pavlasová, L. (2017). Future secondary teachers' knowledge-based reasoning when observing a lesson. Proceedings of the 14th International Conference Efficiency and Responsibility in Education (536-544). Prague: Czech University of Life Sciences.

Vondrová, N. \& Žalská, J. (2015). Ability to notice mathematics specific phenomena: What exactly do student teachers attend to? Orbis scholae, 9(2), 77-101.

LEnKa PAVlasová, lenka.pavlasova@pedf.cuni.cz

Univerzita Karlova, Pedagogická fakulta

Katedra biologie a environmentálních studií

Magdalény Rettigové 4, 11639 Praha 1, Česká republika 